\title{
IMPACT OF SELECTED \\ SOCIO-DEMOGRAPHIC FACTORS ON THE \\ DEVELOPMENT OF MORTALITY DUE TO \\ CIRCULATORY SYSTEM DISEASES IN THE SLOVAK REPUBLIC
}

\author{
Beáta Gavurová, Matúš Kubák \\ Faculty of Economics, Technical University of Košice, Košice, Slovak Republic
}

\begin{abstract}
SUMMARY
Aim: We mapped the situation within a group of diseases of the circulatory system (100-199) in the Slovak Republic during 1996-2014. We focused mainly on spatiotemporal differences in mortality while controlling for age and sex.

Methods: We performed binary logistic regression aiming to reveal socio-demographic factors that influence the odds of dying due to diseases of the circulatory system (100-199). In our analysis, the dependent variable was death diagnosis and the independent variables were age, region, gender, and marital status.

Results: Our findings suggest that odds of dying due to diseases of the circulatory system (100-199) increased for every year of age by $5.4 \%$. Within the period from 1996 to 2014, the risk of dying from diseases of the circulatory system decreased by 2\% every year. We also documented the fact that being female raised the odds of dying due to diseases of the circulatory system (100-199) by $12.9 \%$ compared to males. Furthermore, it could be argued that serious differences in terms of regional distribution of deaths caused by diseases of the circulatory system (I00-I99) exist in the Slovak Republic.

Conclusions: We present the development of diseases of the circulatory system (100-199) in the Slovak Republic. Differences in spatial distribution of deaths are documented as well as related gender differences. Our study can serve as a tool for policy makers and benchmark for professionals.
\end{abstract}

Key words: diseases of the circulatory system, Slovak Republic, binary logistic regression

Address for correspondence: M. Kubák, Faculty of Economics, Technical University of Košice, Němcovej 32, 04001 Košice, Slovak Republic, E-mail: matus.kubak@tuke.sk

https://doi.org/10.21101/cejph.a5054

\section{INTRODUCTION}

Circulatory system diseases are the leading cause of death in Slovakia and the leading cause for hospitalization. They represent a significant medical, social and economic problem. These diseases result in standing mortality worldwide. The only way to eliminate them is a quality prevention and early diagnosis (1). The development of morbidity and mortality of these diseases are affected by numerous factors, some of which can be affected by an individual himself, for example changing lifestyle. Lifestyle and health behaviours can reach up to $60-70 \%$ of influence on the overall health of humans; socio-economic environment 15-20\%; age, genetic and constitutional factors 10-15\%; with the same proportion accounted for by health care. In addition to uncontrollable risk factors (age, gender, family history), morbidity of circulatory system diseases is affected by the so-called controllable factors, such as blood pressure, obesity, diabetes, high cholesterol, smoking, stress, a sedentary lifestyle, etc. The incidence of serious risk factors for circulatory system diseases in Slovak population aged under 65 is in the recent years disap- pointingly high. Concerning negative results, we can mention the observed elevated levels of total cholesterol in 54\% of subjects, elevated blood pressure in $45 \%$ of subjects in the general population, with about half of them had blood pressure above 160/90 $\mathrm{mmHg}$. Moreover, increase in the incidence of hypertension by $6 \%$ was documented, with approximately $62 \%$ being overweight or obese according to the BMI (body mass index) and 49\% have risk values in waist circumference. Additionally, steady rise of smoking among younger age groups or lack of physical activity (no or almost no physical activity in $37 \%$ of men and $50 \%$ women) could be mentioned as well. Expert studies associate these risk factors with age, sex, level of education and the regions of Slovakia, with the worst records among the inhabitants of large cities and in terms of territorial deployment among residents of southern and eastern districts of Slovakia, including negative eating habits. In international comparison, the aggregate population of 0-64 years, Slovakia has the death rate of circulatory system diseases 2.5 times higher than Austria and the EU 15, 1.7 times higher than Finland, 1.2 times higher than Czech Republic, 1.3 times less than Hungary and 2.4 times less than in Ukraine $(2,3)$. 
Many research studies focused on public health $(4,5)$ examine the long-term risk factors of the determinants of health to detect possible causes of health inequalities. Its elimination is a priority of the European Commission, which calls for the introduction of measures to eliminate health inequalities in the European Union (6), which are costly, both economically and socially.

The most typical group of health determinants includes demographic and biological determinants (e.g. age, sex, ethnicity, etc.), socio-economic determinants (lifestyle, education, employment, social contacts, etc.), environmental determinants (life and work) and health system. Estimation of the impact of various determinants on the health of humans differs among domestic and foreign authors. According to several sources, lifestyle and behaviours have the most decisive impact, followed by the environmental, genetic and biological factors as well as health services. The estimated share of health care on health is $10-20 \%$ (7). Health care is very important, although not the largest contributor to health. At least four fifths of efforts to improve the health status should be directed to preventing diseases, using "non-health" factors. The quality of prevention programs will require the implementation of multidimensional analyses with the conceptual medical, social, economic and regional framework, which are still absent in our public health system. The main reason is a lack of high-quality databases, epidemiological and socio-demographic data, research teams and seclusion of results of research activities. This prevents the development of national and international platforms as well as deeper comparative examination of determinants of health risk factors and their causal dimensions. Regular monitoring and evaluation of the social determinants of health in working and living conditions will lead to knowing and elimination of the influence of factors decreasing life expectancy with a negative impact on people's lives, productivity levels and health care spending. These facts determined the logical target of our research study to the effects of selected socio-demographic factors on the development of mortality due to circulatory system diseases in Slovakia.

\section{Literature Review}

Many researchers (8-30) have been examining the impact of age, gender, socioeconomic status, economic characteristics, demographic and sociological factors on mortality of circulatory system diseases for a long time. Their research studies are markedly heterogeneous by nature, since they examine a selected determinant or a group of determinants in relation to circulatory system diseases mortality in different populations only, at different times and through different methodologies. Despite the unification of their conclusions, they provide a valuable platform when considering the significance of selected determinants for further scientific researches. As suggested by some of the tabulated results (Table 1), marital status and socioeconomic status are often the subjects of analysis of causal relations in relation to morbidity and mortality from circulatory system diseases. These determinants are being examined by authors in various research processes and they conclude that single men have a higher risk of mortality due to circulatory system diseases than women. Women who were married or living with a partner had a similar risk of coronary heart disease, but significantly lower mortality, compared with women who were not. Divorce and widowhood was associated with an increased risk of mortality only for men but not women. Low socioeconomic status (SES) increases the risk of circulatory system diseases and deaths from type 1 diabetes. Being married provides up to $50 \%$ lower risk of death from circulatory system diseases with diabetes, as compared to being single. This suggests that single status, divorce and widowhood represent a potential adverse effect on health. Low SES, based on the results of some studies (Table 1), is associated with an increased risk of contracting coronary heart disease. The link between socioeconomic status and cardiovascular risk factors was more consistent among women than men. Several studies in its conclusions appeal to the increasing importance of prevention and treatment of coronary heart disease amongst a part of the population with a distinctive lower SES. The level of education is in some studies considered to be the most important factor among the socioeconomic elements in conjunction with the risk factors of circulatory system diseases. Similar, interesting findings exist; these are reviewed in Table 1. In addition to these factors, regional disparities in deaths due to circulatory system diseases in some countries are a subject of numerous research studies as well. Their creation and reinforcement are the result of the global crisis, the continued deepening of inequalities in health among countries and within some of them, the setting of health systems and many other exogenous and endogenous causes.

\section{MATERIALS AND METHODS}

Analysis was done on dataset containing all deaths in the Slovak republic within period of 1996-2014. In the descriptive part of the paper we offered description of evolution of diseases comprised in the chapter Diseases of the circulatory system (I00-I99) of the 10th revision of International Classification of Diseases in the Slovak Republic during mentioned period. In the quantitative analysis, we used binary logistic regression where we were interested in model comprising dichotomous outcome variables. In the presented logit model the log odds of dying due to the Diseases of the circulatory system (I00-I99) against dying from all the other possible diseases was modelled as a linear combination of the predictor variables. Predictor variables were year of death, age, gender, region and marital status.

\section{RESULTS}

Our dataset contained all deceased persons in Slovak Republic within the period from 1996 to 2014. In total, there were 997,165 observations (deceased individuals). With an enormous predominance, Diseases of the circulatory system were responsible for $53.8 \%$ of deaths. In total, 536,393 individuals died due to Diseases of the circulatory system in Slovak Republic during the previously mentioned 19-year period. Our dataset contained information about deceased individuals via death certificates in the previously outlined time period. The data were provided by the National Health Information Centre of the Slovak Republic.

Figure 1 proposed an overview of evolution of five most frequent causes of death within the Chapter IX - Diseases of the circulatory system. One can see that Ischemic heart diseases (I20-I25) which caused 54.8\% of all deaths within the Diseases 
Table 1. Literature review

\begin{tabular}{|c|c|c|c|}
\hline Source & Variables & Methods & Results \\
\hline Davletov et al. (2015) & Age & $\begin{array}{l}\text { Age-standardized mortality rates } \\
\text { by gender and region } \\
\text { in Kazakhstan }\end{array}$ & $\begin{array}{l}\text { Substantial differences in mortality from cardiovascular disease } \\
\text { across regions equally between men and women have been found. } \\
\text { Hazardous alcohol use appears to be highest in the north-eastern } \\
\text { region of Kazakhstan, which could be associated with different pat- } \\
\text { terns of alcohol consumption across different ethnic groups (ethnic } \\
\text { Russians). }\end{array}$ \\
\hline Naghavi et al. (2015) & Age, sex & $\begin{array}{l}\text { Global Burden of Disease Study } \\
\text { 2013; } 188 \text { countries between } \\
1990 \text { and } 2013\end{array}$ & $\begin{array}{l}\text { Evaluation of the epidemiological convergence of the country de- } \\
\text { pends on whether absolute or relative measure of inequality is being } \\
\text { used. However, the age-standardized mortality rate for the seven } \\
\text { principal causes of mortality is increasing, suggesting a reversal in } \\
\text { some countries. }\end{array}$ \\
\hline Rawshani et al. (2015) & $\begin{array}{l}\text { Income, educa- } \\
\text { tion, marital status, } \\
\text { birthplace (region), } \\
\text { comorbidity }\end{array}$ & $\begin{array}{l}\text { Cox regression, rigorous } \\
\text { covariate adjustment }\end{array}$ & $\begin{array}{l}\text { Low SES (socioeconomic status) increases the risk of CVD and } \\
\text { death in type } 1 \text { diabetes. Being married brings about } 50 \% \text { lower risks } \\
\text { for death from CVD and diabetes compared to be single. }\end{array}$ \\
\hline Roth et al. (2015) & Regions, age, sex & $\begin{array}{l}\text { Regional comparison of } \\
\text { cardiovascular mortality from } \\
1990 \text { to } 2013\end{array}$ & $\begin{array}{l}\text { Over the past two decades there has been a reduction in mortality } \\
\text { from CVD but also a growing number of people who are diagnosed } \\
\text { with cardiovascular disease at a young age. There is wide varia- } \\
\text { tion between and within regions, CVD remain a dominant cause of } \\
\text { death also in individuals younger than } 40 \text { years. Policies and health } \\
\text { interventions must be adapted to a wide variety of local conditions in } \\
\text { order to achieve the objectives set by the UN for the 2025th }\end{array}$ \\
\hline Yang et al. (2015) & $\begin{array}{l}\text { Regions, socio-eco- } \\
\text { nomic and demograph- } \\
\text { ic indicators }\end{array}$ & $\begin{array}{l}26 \text { studied regions in the south } \\
\text { and west of China in the years } \\
2008 \text { to } 2011 \text { to identify the } \\
\text { socio-economic and demographic } \\
\text { factors, combined with differences } \\
\text { in temperature; Poisson general- } \\
\text { ized additive model (GAM) }\end{array}$ & $\begin{array}{l}\text { In most areas it has been an increasing trend in high or low tempera- } \\
\text { ture associated with increased cardiovascular mortality. Cardiovas- } \\
\text { cular mortality in combination with a low temperature is affected } \\
\text { by factors: years of education, the percentage of the population } \\
\text { over } 65 \text { and the percentage of women. Cardiovascular mortality in } \\
\text { association with high temperature is affected by factors: the number } \\
\text { of beds, the percentage of the population working in industry and the } \\
\text { percentage of women. }\end{array}$ \\
\hline Floud et al. (2014) & $\begin{array}{l}\text { Marital status of } \\
\text { women }\end{array}$ & $\begin{array}{l}\text { 734,626 women (average age } \\
\text { 60), Cox regression }\end{array}$ & $\begin{array}{l}\text { Women who were married or living with a partner had a similar risk } \\
\text { of coronary heart disease but significantly lower death rates from } \\
\text { coronary heart disease compared with women who were not married } \\
\text { or did not live with a partner. }\end{array}$ \\
\hline Moran et al. (2014) & Region, age & 21 world regions & $\begin{array}{l}\text { In most regions of the world, particularly in high-income age- } \\
\text { standardized death rate from ischemic heart disease has been } \\
\text { declining since 1980. The high age-standardized death rate from } \\
\text { ischemic heart disease in Eastern Europe, Central Asia and South } \\
\text { Asia highlights the need for prevention and control of risk factors in } \\
\text { these areas and research of unique behavioural and environmental } \\
\text { determinants of increased mortality from ischemic heart disease. }\end{array}$ \\
\hline Quinones et al. (2014) & Marital status, sex, age & $\begin{array}{l}3,766 \text { men and women aged } \\
28-74 \text { years who survived } 28 \\
\text { days after overcoming the first } \\
\text { heart attack; Hazard ratios }\end{array}$ & $\begin{array}{l}\text { Marital status has a strong protective effect on survival of first } \\
\text { myocardial infarct with a diagnosed hyperlimidemy that decreases } \\
\text { with increasing age. Treatment recommending lifestyle changes or } \\
\text { other attributes specific to hyperlimidemy may be essential factors } \\
\text { mediated through social support of the spouses. }\end{array}$ \\
\hline Mikkola et al. (2013) & Sex, age & $\begin{array}{l}\text { Annual mortality rates were } \\
\text { calculated on the 100,000 inhabit- } \\
\text { ants of middle-aged separately for } \\
\text { men and women separately for } \\
\text { the 5-year categories. }\end{array}$ & $\begin{array}{l}\text { The mortality rate from heart disease in men increases at a relatively } \\
\text { young age, but the risk among women increases sharply after } 60 \\
\text { years of age. Identified data highlight the need to identify and avoid } \\
\text { risk factor for CVD, especially in middle-aged women. }\end{array}$ \\
\hline Roche et al. (2013) & Sex & $\begin{array}{l}73,783 \text { people aged } 25 \text { years and } \\
\text { over in Newfoundland and Lab- } \\
\text { rador, Canada ( } 15,152 \text { diabetes; } \\
9,517 \text { of late diagnosis) }\end{array}$ & $\begin{array}{l}\text { Men and women with diabetes had an increased risk of death in all } \\
\text { cases also CVD than people who did not have diabetes, and the risk } \\
\text { is greater in women than in men. Women with late onset diabetes } \\
\text { had a higher risk compared to women without diabetes, but the two } \\
\text { groups have a significantly higher risk than men. }\end{array}$ \\
\hline
\end{tabular}

Continued on next page 
Continued from previous page

\begin{tabular}{|c|c|c|c|}
\hline Source & Variables & Methods & Results \\
\hline Tanno et al. (2013) & $\begin{array}{l}\text { Marital status, dura- } \\
\text { tion of dialysis, BMI, } \\
\text { systolic blood pres- } \\
\text { sure, cholesterol, high } \\
\text { density of lipoprotein- } \\
\text { cholesterol, albumin, } \\
\text { C-reactive protein, } \\
\text { comorbidity, smoking, } \\
\text { alcohol, education, } \\
\text { employment }\end{array}$ & $\begin{array}{l}5 \text {-year study, } 1,064 \text { hemodialyc } \\
\text { patients aged } 30 \text { years and older; } \\
\text { Cox regression - hazard ratios }\end{array}$ & $\begin{array}{l}\text { The results show that single status is a significant predictor of mor- } \\
\text { tality for all CVD and mortality, and the distribution / survivorship is a } \\
\text { significant predictor of CVD mortality in dialysis patients }\end{array}$ \\
\hline Gupta et al. (2012) & $\begin{array}{l}\text { Region, age, gender } \\
\text { (smoking, tobacco use, } \\
\text { low physical activity, } \\
\text { obesity, hypertension, } \\
\text { diabetes) }\end{array}$ & & $\begin{array}{l}\text { The study indicates that there are significant regional differences in } \\
\text { risk factors in India. Regional differences in risk factors on macro } \\
\text { level explain some of the regional differences in mortality due to } \\
\text { cardiovascular disease. Further study where there is a comparison } \\
\text { of different risk factors for cardiovascular disease in different regions } \\
\text { needed and correlate them with differences in mortality from cardio- } \\
\text { vascular disease by using a single system. }\end{array}$ \\
\hline Franks et al. (2011) & $\begin{array}{l}\text { Socio-economic status } \\
\text { (SES) - income, } \\
\text { education }\end{array}$ & $\begin{array}{l}\text { 10-year study of } 15,495 \text { people } \\
\text { aged } 45-64 \text { years; Cox analysis, } \\
\text { Farmingham Risk Score }\end{array}$ & $\begin{array}{l}\text { Low SES is associated with increased risk of coronary heart disease. } \\
\text { After adjustment for variable time-dependent, the effect of SES } \\
\text { remained significant. }\end{array}$ \\
\hline Franks et al. (2010) & $\begin{array}{l}\text { Socioeconomic } \\
\text { status (SES) - income, } \\
\text { education }\end{array}$ & $\begin{array}{l}\text { 10-year study, } 15,495 \text { adults } \\
\text { aged } 45-64 \text { years, Cox method, } \\
\text { Framingham risk score }\end{array}$ & $\begin{array}{l}\text { The use of the income of patients on the basis of the blocking group } \\
\text { and individual education minimizes distortion of SES and Framing- } \\
\text { ham risk score suggests a more aggressive treatment of cholesterol } \\
\text { in those with low SES. }\end{array}$ \\
\hline Stringhini et al. (2010) & $\begin{array}{l}\text { Social status, income, } \\
\text { level of responsibility } \\
\text { at work }\end{array}$ & $\begin{array}{l}\text { 9,590 men and women deceased } \\
\text { till } 2009\end{array}$ & $\begin{array}{l}\text { Low socio-economic position brought about } 1.6 \text { times higher risk } \\
\text { of death in all cases of death in the population working in the civil } \\
\text { service in London as reflected in health behaviour. }\end{array}$ \\
\hline Loucks et al. (2009) & $\begin{array}{l}\text { Sex, age (systolic } \\
\text { blood pressure, the } \\
\text { level of HDL choles- } \\
\text { terol, BMI, smoking, } \\
\text { "Fasting Glucose", use } \\
\text { of antihypertensive } \\
\text { drugs) }\end{array}$ & $\begin{array}{l}1,835 \text { subjects of the Framingham } \\
\text { Heart Study Offspring Cohort be- } \\
\text { tween years } 1971 \text { and 2003; Cox } \\
\text { proportional hazards analyzes }\end{array}$ & $\begin{array}{l}\text { The findings highlight the potential importance of prevention and } \\
\text { treatment of ischemic heart disease for those who have recorded low } \\
\text { socio-economic position. }\end{array}$ \\
\hline Molloy et al. (2009) & Marital status, sex & $\begin{array}{l}\text { 13,889 Scottish men and women } \\
\text { without a history of clinically diag- } \\
\text { nosed cardiovascular disease }\end{array}$ & $\begin{array}{l}\text { Risk of cardiovascular mortality was the largest ever among the } \\
\text { single and never married males and among the separated / divorced } \\
\text { women compared with those who were married, modifying data on } \\
\text { age and socio-economic factors. }\end{array}$ \\
\hline Ikeda et al. (2007) & Marital status, sex & $\begin{array}{l}\text { 94,062 Japanese men and } \\
\text { women aged 40-79; question- } \\
\text { naire }\end{array}$ & $\begin{array}{l}\text { Single marital status was associated with a higher risk of mortality } \\
\text { than married, same for women and men. Divorce and widowhood } \\
\text { was associated with an increased risk only for men but not for } \\
\text { women. This suggests that single status, divorce and widowhood } \\
\text { represent a potential adverse effect on health. }\end{array}$ \\
\hline $\begin{array}{l}\text { Woodward et al. } \\
\text { (2007) }\end{array}$ & $\begin{array}{l}\text { Sex, age, marital } \\
\text { history }\end{array}$ & $\begin{array}{l}\text { 6,540 men and 6,757 women } \\
\text { aged 30-74 years, ASSIGN score } \\
\text { (cardiovascular risk score) }\end{array}$ & $\begin{array}{l}\text { Conventional cardiovascular score failed in the focus of social } \\
\text { disparities in the course of the disease. Family history is a valuable } \\
\text { indicator not only of ethnic sensitivity. ASSIGN score classified more } \\
\text { people with the social deprivation and a positive family history of } \\
\text { high risk. }\end{array}$ \\
\hline Zhang (2006) & Marital status - history & $\begin{array}{l}\text { Logistic regression models and } \\
\text { mortality data on CVD from } 1992 \\
\text { (Health and Retirement Study) }\end{array}$ & $\begin{array}{l}\text { Middle-aged married and those who have never been married are } \\
\text { the CVD healthiest. People who repeatedly changed their marital } \\
\text { status have a higher chance of developing CVD and require care } \\
\text { primarily in old age. }\end{array}$ \\
\hline Malyutina et al. (2004) & $\begin{array}{l}\text { Marital status, gender, } \\
\text { education }\end{array}$ & $\begin{array}{l}485 \text { men and } 4919 \text { women aged } \\
25-64 \text { years in years }(1984, \\
\text { 1985/86, 1988/89, 1994/95). } \\
\text { Method: questionnaire }\end{array}$ & $\begin{array}{l}\text { Educational differences in cardiovascular mortality in Russia has a } \\
\text { similar direction as in Western countries. Educational differences in } \\
\text { cardiovascular mortality in women and increased mortality among } \\
\text { divorced men could not be explained by traditional risk factors. }\end{array}$ \\
\hline
\end{tabular}


Continued from previous page

\begin{tabular}{|l|l|l|l|}
\hline Source & Variables & Methods & Results \\
\hline Cheung (2000) & $\begin{array}{l}\text { Marital status, age of } \\
\text { the woman }\end{array}$ & $\begin{array}{l}\text { Women aged 35 and over; Cox } \\
\text { regression }\end{array}$ & $\begin{array}{l}\text { Being single has been associated with higher mortality. Causal } \\
\text { interpretation is unlikely. Increased mortality was detected as a result } \\
\text { of divorce or widowhood. }\end{array}$ \\
\hline Yu et al. (2000) & $\begin{array}{l}\text { SES (education, occu- } \\
\text { pation, income, marital } \\
\text { status), blood pres- } \\
\text { sure, BMl, smoking }\end{array}$ & $\begin{array}{l}\text { The level of education seems to be the most important factor from } \\
\text { the remaining socio-economic factors in conjunction with the risk } \\
\text { factors of cardiovascular disease. People with lower socio-economic } \\
\text { status have higher levels of cardiovascular risk factors. The link } \\
\text { between socio-economic status and cardiovascular risk factors was } \\
\text { more consistent in women than in men. }\end{array}$ \\
\hline
\end{tabular}

of the circulatory system displayed serious increment during a period of 2006-2008. After this period, the evolution of deaths started to decline again. Cerebrovascular diseases (I60-I69) that caused $17.8 \%$ of deaths within Diseases of the circulatory system had also shown significant rise within the period of 2006-2008. Afterwards, the number of deaths started to decrease. The number of deaths caused by Diseases of arteries, arterioles and capillaries (I70-I79) that caused 9.2\% of deaths in the chapter Diseases of the circulatory system had been decreasing within the period between 1996-2004. From 2004-2006 we observed serious rise in the number of deaths. From 2006-2014, number of deaths within this group of diseases displayed considerable decrease. Situation within the group of Other forms of heart disease (I30-I52) that caused $7 \%$ of all deaths within the chapter Diseases of the circulatory system got worse over time. The situation within the group of Hypertensive diseases (I10-I15) that caused 7\% of all deaths within Chapter IX worsened seriously from 1998-2001 and then remained stable. Situation in this group ameliorated from 2006.

In Table 2, information about the spatial and gender distribution of deaths was provided. Table 2 suggests that among Diseases of the circulatory system, the most dangerous were Ischemic heart diseases (I20-I25), Cerebrovascular diseases (I60-I69), Diseases of arteries, arterioles and capillaries (I70-I79), Hypertensive diseases (I10-I15) and Other forms of heart disease (I30-I52). One could say that the most frequent occurrence of Diseases of the circulatory system per capita was in Nitra region, followed by Banská Bystrica region and Trenčín region. Concerning differences between genders, $53.7 \%$ of all deceased persons due to Diseases of the circulatory system were females. Females are more likely to die due to Diseases of the circulatory in every block of diagnosis, except Other forms of heart disease (I30-I52), where a count of deaths was equal for both genders.

Table 3 depicted the situation from the perspective of age. One can see that the percentage of died from Diseases of the circulatory system increased consistently. In the age under 40 years, Diseases of the circulatory system were not a serious problem. In the age interval 41-50, every fourth person died due to Diseases of the circulatory system, in the age interval 51-60, every third person died due to Diseases of the circulatory system. At the age over 61 years, every second person died due to Diseases of the circulatory system and ratio did worsen as people got older.

Figure 2 revealed some interesting facts. We used boxplots for our analysis. The bottom of the box indicates the 25th percentile. It means that $25 \%$ of observations were situated below; while the top of the box represents the 75 th percentile, thus $25 \%$ of observations have values above the 75th percentile. Therefore, $50 \%$ of the observations should lie within the box. Firstly, it can be concluded that in all groups of diagnosis the median age of death (dark line in the boxes) was lower for males than for females. Furthermore, whiskers (T-bars that extend from the boxes) extend less for females compared to males in all diagnoses groups, which indicate that death age varied less for females than for males. Additionally, whiskers in cases of males were always lower compared to females, which suggested that the minimal age of death was lower for males. If the data were normally distributed, we should expect $95 \%$ of the data to lie between the whiskers. On the other hand, we should look upon outliers in bottom side of whiskers. Outliers are represented by points - extreme values and stars

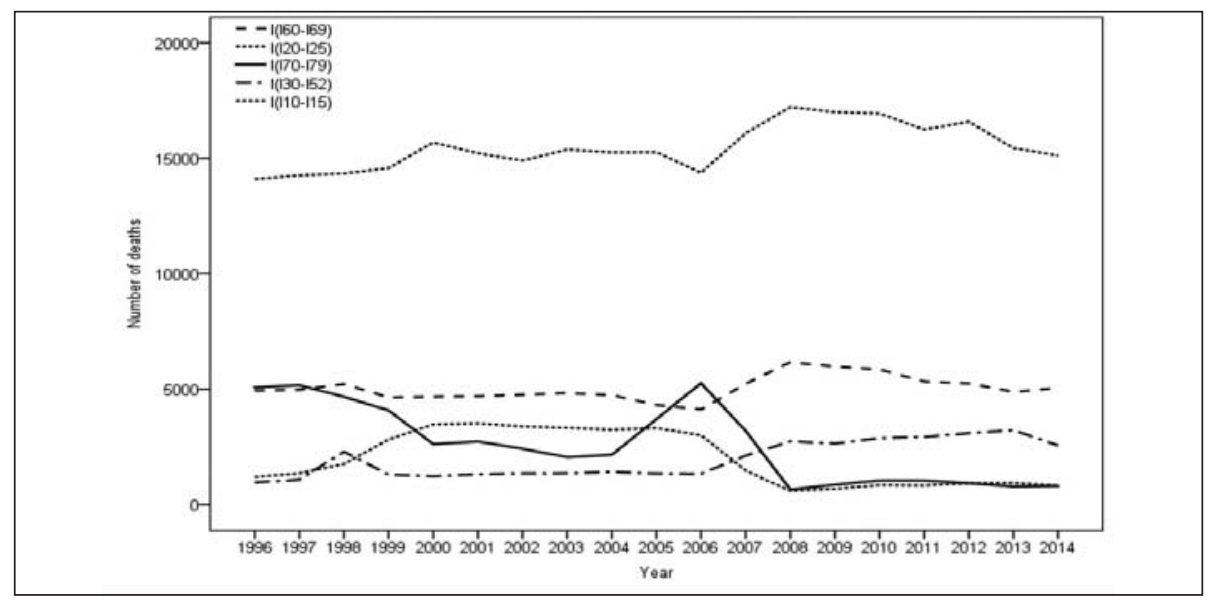

Fig. 1. Evolution of deaths in time. 
Table 2. Number of deaths caused by diseases of the circulatory system, 1996-2014 (cross tabulation - block of diagnosis, region, and gender)

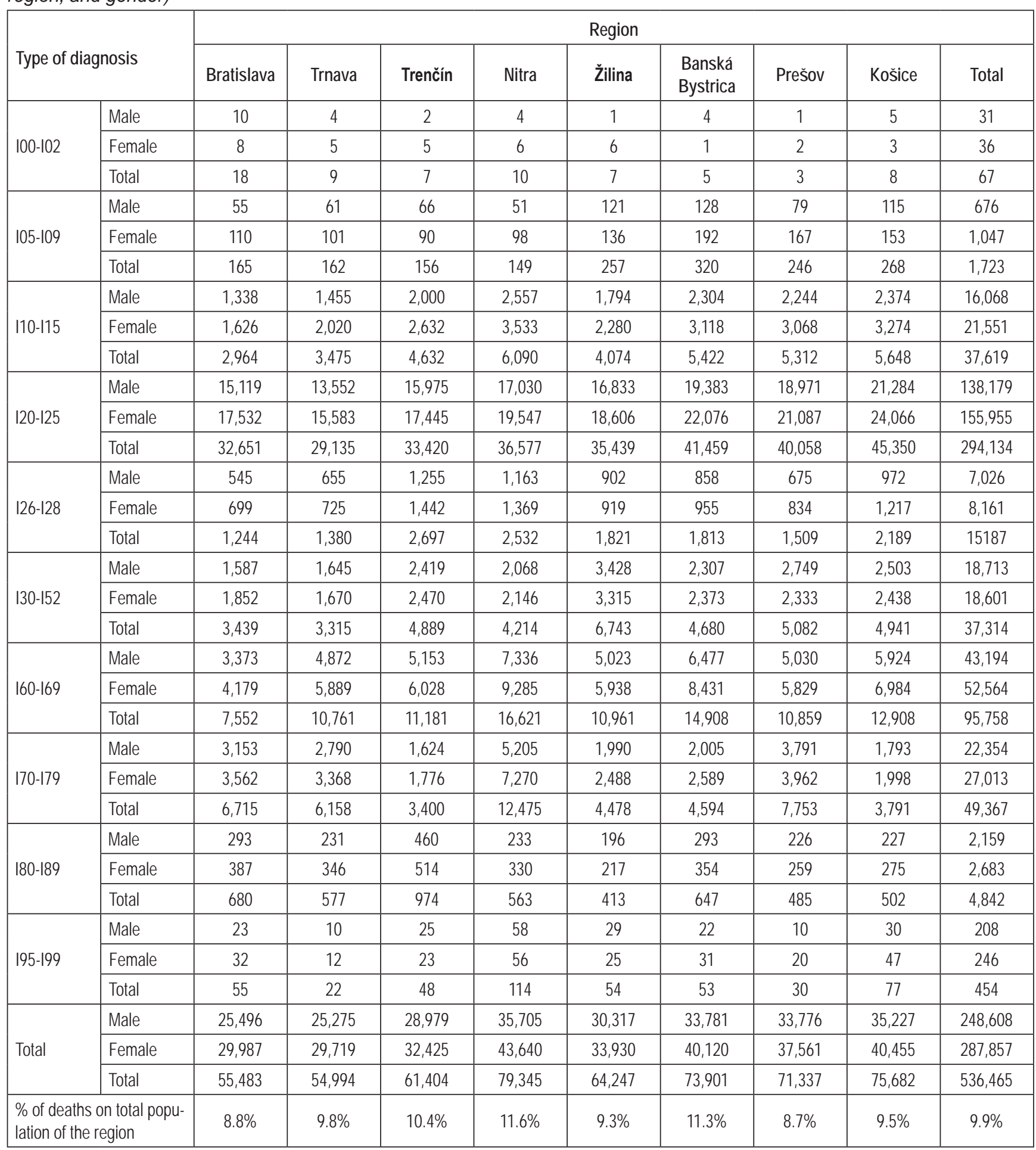

- extreme outliers. In case of Hypertensive diseases (I10-I15) both genders did reach extreme outliers, but the minimal age of death was resolutely higher in case of females. Moreover, the median age of deaths was higher in case of females. Concerning Ischemic heart diseases (I20-I25), the most dangerous diagnosis within the Chapter IX, it could be argued that the minimal age of death is much lower in the case of males. On the other hand, maximal age of death is higher. Moreover, the males' box was wider, which suggested that deaths age varies more for males compared to females. In terms of Other forms of heart disease
(I30-I52), the gender difference was obvious. Median age of death was much lower for males compared to females. The males' box was nearly twice as wide as females', which suggested that age of death varied less for females compared to males. Moreover, the lowest age of death was much lower for males compared to females. In the case of Cerebrovascular diseases (I60-I69) a similar pattern, comparable to other diagnostic groups could be observed for both genders. In terms of Diseases of arteries, arterioles and capillaries (I70-I79) we saw similar pattern as in the case of other diseases. 
Table 3. Diseases of the circulatory system and age

\begin{tabular}{|l|c|c|c|c|}
\hline Age interval & $\begin{array}{c}\text { Deaths caused by other } \\
\text { diseases }\end{array}$ & $\begin{array}{c}\text { Deaths caused by } \\
\text { diseases of the circulatory } \\
\text { system }\end{array}$ & Total number of deaths & $\begin{array}{c}\text { Percentage of deaths } \\
\text { caused by diseases } \\
\text { of the circulatory system }\end{array}$ \\
\hline $0-10$ & 10,161 & 240 & 10,401 & 2.3 \\
\hline $11-20$ & 5,071 & 297 & 5,368 & 5.5 \\
\hline $21-30$ & 10,435 & 868 & 11,303 & 7.7 \\
\hline $31-40$ & 17,424 & 3,280 & 20,704 & 15.8 \\
\hline $41-50$ & 43,449 & 14,844 & 58,293 & 25.5 \\
\hline $51-60$ & 78,885 & 40,352 & 119,237 & 33.8 \\
\hline $61-70$ & 99,664 & 84,559 & 184,223 & 45.9 \\
\hline $71-80$ & 114,584 & 170,851 & 285,435 & 59.9 \\
\hline $81-90$ & 70,861 & 179,773 & 250,634 & 71.7 \\
\hline $91-100$ & 10,134 & 40,677 & 50,811 & 80.1 \\
\hline $101-110$ & 104 & 652 & 756 & 86.2 \\
\hline
\end{tabular}

\section{Binary Logistic Regression}

In line with the objective, binary logistic regression was used, which is a specific case of the generalized linear model. Our aim is to reveal socio-demographic factors that influence the odds of dying, or not dying due to Diseases of the circulatory system. Binary logistic regression is analogous to linear regression. In binary logistic regression the dependent variable is binary, thus has a dichotomous nature. Binary logistic regression overcomes many of the restrictive assumptions of linear regressions. While using binary logistic regression, dependent variable does not need to be normally distributed. Furthermore, this method does not require a linear relationship between the dependent variable and regressors. In binary logistic regression residuals need to be independent, but need not be normally distributed. The only assumption to be satisfied is an assumption of non-multicollinearity of explanatory variables which is fulfilled in our case.

In our analysis, the dependent variable was death diagnosis and the explanatory variables were year, age, region, gender and marital status. Dependent variable took the value 0, when one died of diagnosis other than diagnoses listed in the chapter Diseases of the circulatory system; and value 1 in cases, when one died due to some diagnosis listed in chapter Diseases of the circulatory system. There were five independent, explanatory variables which were coded as follows. Year of death is continuous variable which indicate a time of death. Age is a scalar variable which reaches values from 0 to 108 , thus the youngest deceased individual was 0 years old and the oldest one was 108 years old. The region was nominal variable with 8 levels: Bratislava region, Trnava region, Trenčín region, Nitra region, Žilina region, Banská Bystrica region, Prešov region and Košice region. The variable region represented the place where one died. It did not represent the place of birth, or place of residence, but place of death. Bratislava region was set as the reference category, because this region was medially populated compared to other regions. Gender was a binary categorical variable which was coded 0 for males and 1 for females. Males were set as the reference category in our regression. Marital status was a categorical variable which achieved four levels: single, married, divorced and widowed. In our analysis, marital status-single was set as the reference category. Results of binary logistic regression can be found in Table 4 . All obtained regression coefficients were statistically significant; moreover, the model as a whole was statistically significant. It could be said, that the evident statistical significance was reached by the mere fact that our dataset was huge.

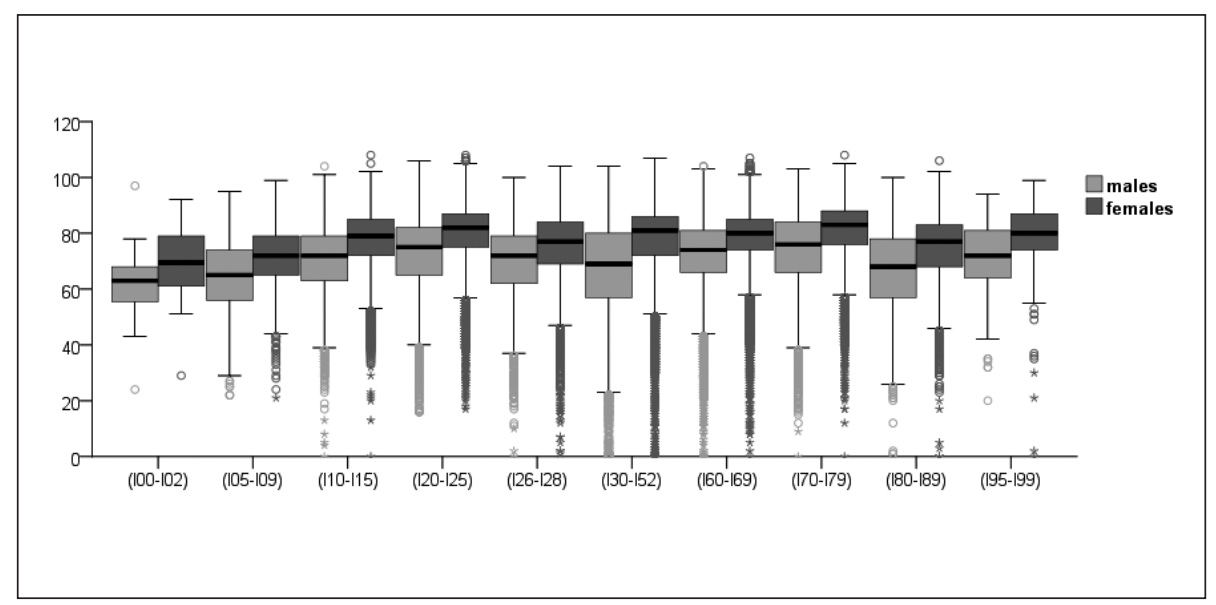

Fig. 2. Boxplot: Age, Gender, Diagnosis. 
Table 4. Odds of dying from cardiovascular diseases according to Year, Age, Gender, region and Marital status

\begin{tabular}{|l|c|c|c|c|c|}
\hline & B coefficient & Standard error & Degrees of freedom & p-value & Odds ratio \\
\hline Year & -0.020 & 0.010 & 1 & $<0.001$ & 0.980 \\
\hline Age & 0.052 & 0.150 & 1 & $<0.001$ & 1.054 \\
\hline Gender - females & 0.122 & 0.005 & 1 & $<0.001$ & 1.129 \\
\hline Region & & & 7 & $<0.001$ & \\
\hline Trnava & 0.135 & 0.009 & 1 & $<0.001$ & 1.145 \\
\hline Trenčín & 0.245 & 0.009 & 1 & $<0.001$ & 1.277 \\
\hline Nitra & 0.128 & 0.009 & 1 & $<0.001$ & 1.133 \\
\hline Žilina & 0.171 & 0.009 & 1 & $<0.001$ & 1.189 \\
\hline Banská Bystrica & 0.232 & 0.009 & 1 & $<0.001$ & 1.258 \\
\hline Prešov & 0.344 & 0.009 & 1 & $<0.001$ & 1.415 \\
\hline Košice & 0.282 & 0.009 & 3 & $<0.001$ & 1.328 \\
\hline Marital status & & & 1 & $<0.001$ & \\
\hline Married & -0.172 & 0.008 & 1 & $<0.001$ & 0.830 \\
\hline Divorced & -0.093 & 0.011 & 1 & $<0.001$ & 0.914 \\
\hline Widowed & -0.001 & 0.009 & 0.015 & $<001$ & 0.985 \\
\hline Constant & -3.717 & & 1 & $<.001$ & 0.024 \\
\hline
\end{tabular}

Bratislava region is the reference category for region.

Single people are the reference category for marital status.

Table 4 indicated following findings. Year by year the number of deaths caused by Diseases of the circulatory system has been decreasing by $2 \%$. Age had a positive influence on odds of dying due to Diseases of the circulatory system. Therefore, one unit increase in age increased the chance of dying due to Diseases of the circulatory system, while controlling for other explanatory variables. This chance increased every additional year of living by $5.4 \%$. This conclusion suggested that the older the individual, the odds of dying due to Diseases of the circulatory system increased, with respect to other diagnoses. Concerning gender, our findings suggested that being female raised the odds of dying due to Diseases of the circulatory system by $12.9 \%$ compared to males. Regarding the variable region (i.e. place of death), Bratislava region was set as reference category. It could be concluded, that in every region compared to reference region of Bratislava, the odds of dying due to Diseases of the circulatory system was higher, in context of the fact that there were other explanatory variables in the model as well. The odds of dying due to Diseases of the circulatory system were higher by $14.5 \%$ in the Trnava region, by $27.7 \%$ higher in the Trenčín region, by $13.3 \%$ higher in the Nitra region, by $18.9 \%$ higher in the Žilina region, by 25.8\% higher in the Banská Bystrica region, by $41.5 \%$ higher in the Prešov region and by $32.8 \%$ higher in the Košice region when compared to Bratislava region. Apropos of the marital status, where single people were set as the reference category, the findings suggested that married individuals have lower chance of dying due to Diseases of the circulatory system (by 17\%) compared to single individuals, followed by divorced individuals (8.6\%). Additionally, widowed individuals had approximately the same chance of dying due to Diseases of the circulatory system as single people had. However, one should keep in mind that our findings might be skewed by suppression effect which usually occurs in the binary logistic regression.

\section{DISCUSSION}

These alarming results about the number of deaths from circulatory system diseases raise discussion not only about the possible causes of death, but also about possible bad marking of individual diseases in health statistics in Slovakia. According to the Slovak Society of Cardiology, some diagnoses are overvalued and others undervalued in favour of other diagnoses. When a sudden death occurs, heart attack is often marked as the cause of death. However, it often does not reflect reality. High number of patients die due to the complications developed after the myocardial infarction. Therefore, it should be desirable to identify the exact cause of death. Additionally, the death rate of circulatory system diseases has substantially increased, even if the patient suffers from diabetes and kidney disease.

Slovakia has one of the highest rates of mortality due to circulatory system diseases which might be caused by a large number of myocardial infarction cases. This might be avoidable through effective prevention. Furthermore, if the myocardial infarction occurred while the patient is in relatively good health and being provided with quality healthcare the odds of dying would be significantly smaller. Therefore, it should be imperative to create a working platform, which will be the basis for long-term cooperation of the key organizations, particularly the Ministry of Health, Slovak Society of Cardiology as well as representatives of insurance companies and patient organizations. Also, it is necessary to implement all general practitioners and health insurance companies to a preventive screening programme of risk factors for premature and preventable mortality.

Unfortunately, no active prevention program for circulatory system diseases currently exists in Slovakia. The last one - "The national program for the prevention of diseases of the heart and blood vessels” was realised in 2011 (31). This included a variety 
of educational activities, such as TV spots, leaflets, banners, as well as measuring cholesterol and blood pressure. The project was accompanied by the campaign "Know the symptoms of heart attack and stroke", where health professionals answered questions and explained symptoms to people in shopping malls. In our opinion, this type of prevention programs provides only the short-time effect. We should build awareness and educate the public about heart diseases regularly. Prevention programme should implement also a group of conditions and diseases including metabolic syndrome (obesity, diabetes mellitus, non-alcoholic steatohepatitis), which are part of the cardiovascular comorbidity and increased mortality and not to be confined only to the cardiovascular system. Accordingly, excessive alcohol consumption can cause mortality for cardiovascular outcomes (bleeding in the brain, malignant arrhythmias, alcoholic cardiomyopathy, etc.). With respect to the Slovak national particularities and a high level of spirits consumption, a campaign to reduce alcohol consumption should be part of the prevention programme mentioned. In this aspect, it is necessary to put pressure on the policy makers and to emphasize the effectiveness of national policies in terms of the limited alcohol advertising in all media, including advertisements and the internet and efficiency of increasing taxes on alcohol.

It is necessary to use innovative technology and advanced treatment for patients, and optimise their system of management and early detection of disease. If we want to reduce the number of premature deaths in Slovakia, without increased interest in the issue of circulatory system diseases will not do.

\section{CONCLUSIONS}

Prevention of heart failure is largely intertwined with the issues of prevention of the circulatory system diseases. The aim of primary prevention is to reduce the incidence of ischemic heart disease which is the most common cause of heart failure. This can only be achieved through systematic and purposeful education of the public about the risk factors of cardiovascular diseases and the need for a healthy lifestyle. These objectives are in the interest of the whole society and an urgent cooperation of numerous public sector institutions is needed for their successful achievement. In terms of health care system, making obligatory, regular preventive examinations should be one of the first steps, especially for at-risk population, aimed to detect and lower related risk factors.

\section{Acknowledgement}

The work was supported by the VEGA Project No. 1/0945/17 Economic research on quantification of marketing processes aimed at improving value for patient, multidimensional analyses of the marketing mix of healthcare facilities and quantification of their importance in the process of establishment of the system to measure the quality and efficiency in healthcare of the Slovak Republic.

\section{Conflict of Interests}

None declared

\section{REFERENCES}

1. Gavurová B, Vagašová T. Regional differences of standardised mortality rates for ischemic heart diseases in the Slovak Republic for the period 1996-2013 in the context of income inequality. Health Econ Rev. 2016;6:21. doi:10.1186/s13561-016-0099-1.

2. Sedláková D. WHO in 2015 in relation to health policy [Internet]. Slovakia: WHO Country Office in Slovakia; 2015 [cited 2016 Nov 2]. Available from: http://www.who.sk/wp-content/uploads/2016/05/Sedlakova.pdf.

3. The Center for Economic Development. Health determinants. In: National Human Development Report [Internet]. Slovakia: The Center for Economic Development; 2003 [cited 2016 Nov 2]. Available from: http:// www.cphr.sk/undp2002.htm. (In Slovak.)

4. Šoltés V, Gavurová B. The possibilities of day surgery system development within the health policy in Slovakia. Health Econ Rev. 2014;4:35. doi:10.1186/s13561-014-0035-1.

5. Šoltés V, Gavurová B. The Functionality comparison of the health care systems by the analytical hierarchy process method. E M Ekon Manag. 2014;17(3):100-17.

6. European Commission. Report on health inequalities in the European Union [Internet]. Brussels: Commission staff working document; 2013 [cited 2016 Nov 2]. Available from: http://ec.europa.eu/health// sites/health/files/social_determinants/docs/report_healthinequalities_swd_2013_328_en.pdf.

7. Aday LA, Begley CR, Lairson DR, Slater CH. Evaluating health care systems. Michigan: Health Administration Press; 1993.

8. Davletov K, McKee M, Berkinbayev S, Battakova Z, Vujnovic M, Rechel B. Regional differences in cardiovascular mortality in Kazakhstan: further evidence for the 'Russian mortality paradox'? Eur J Public Health. 2015;25(5):890-4.

9. Naghavi M, Wang H, Lozano R, Davis A, Liang X, Zhou M, et al. Global, regional, and national age-sex specific all-cause and cause-specific mortality for 240 causes of death, 1990-2013: a systematic analysis for the Global Burden of Disease Study 2013. Lancet. 2015;385(9963):117-71.

10. Rawshani A, Svensson AM, Rosengren A, Eliasson B, Gudbjörnsdottir S. Impact of socioeconomic status on cardiovascular disease and mortality in 24,947 individuals with type 1 diabetes. Diabetes Care. 2015;38(8):151827.

11. Roth GA, Huffman MD, Moran AE, Feigin V, Mensah GA, Naghavi M, et al. Global and regional patterns in cardiovascular mortality from 1990 to 2013. Circulation. 2015;132(17):1667-78.

12. Yang X, Li L, Wang J, Huang J, Lu S. Cardiovascular mortality associated with low and high temperatures: determinants of inter-region vulnerability in china. Int J Environ Res Public Health. 2015;12(6):5918-33.

13. Floud S, Balkwill A, Canoy D, Wright FL, Reeves GK, Green J, et al. Marital status and ischemic heart disease incidence and mortality in women: a large prospective study. BMC Med. 2014 Mar 12;12:42. doi: 10.1186/1741-7015-12-42.

14. Moran AE, Forouzanfar MH, Roth G, Mensah G, Ezzati M, Murray CJ, et al. Temporal trends in ischemic heart disease mortality in 21 world regions, 1980-2010: The Global Burden of Disease 2010 Study. Circulation. 2014;129(14):1483-92.

15. Quinones PA, Kirchberger I, Heier M, Kuch B, Trentinaglia I, Mielck A, et al. Marital status shows a strong protective effect on long-term mortality among first acute myocardial infarction-survivors with diagnosed hyperlipidemia - findings from the MONICA/KORA myocardial infarction registry. BMC Public Health. 2014 Jan 30;14:98. doi: 10.1186/14712458-14-98.

16. Mikkola TS, Gissler M, Merikukka M, Tuomikoski P, Ylikorkala O. Sex differences in age-related cardiovascular mortality. PLoS One. 2013 May 20;8(5):e63347. doi: 10.1371/journal.pone.0063347.

17. Roche MM, Wang PP. Sex differences in all-cause and cardiovascular mortality, hospitalization for individuals with and without diabetes, and patients with diabetes diagnosed early and late. Diabetes Care. 2013;36(9):2582-90.

18. Tanno K, Ohsawa M, Itai K, Kato K, Turin TC, Onoda T, et al. Associations of marital status with mortality from all causes and mortality from cardiovascular disease in Japanese haemodialysis patients. Nephrol Dial Transplant. 2013;28(4):1013-20.

19. Gupta R, Guptha S, Sharma KK, Gupta A, Deedwania P. Regional variations in cardiovascular risk factors in India: India heart watch. World J Cardiol. 2012;4(4):112-20.

20. Franks P, Winters PC, Tancredi DJ, Fiscella KA. Do changes in traditional coronary heart disease risk factors over time explain the association between socio-economic status and coronary heart disease? BMC Cardiovasc Disord. 2011 Jun 3;11:28. doi: 10.1186/1471-2261-11-28.

21. Franks P, Tancredi DJ, Winters P, Fiscella K. Including socioeconomic status in coronary heart disease risk estimation. Ann Fam Med. 2010;8(5):447-53. 
22. Stringhini S, Sabia S, Shipley M, Brunner E, Nabi H, Kivimaki M, et al. Association of socioeconomic position with health behaviors and mortality. JAMA. 2010;303(12):1159-66.

23. Loucks EB, Lynch JW, Pilote L, Fuhrer R, Almeida ND, Richard H, et al. Life-course socioeconomic position and incidence of coronary heart disease the Framingham Offspring Study. Am J Epidemiol. 2009;169(7):82936.

24. Molloy GJ, Stamatakis E, Randall G, Hamer M. Marital status, gender and cardiovascular mortality: behavioural, psychological distress and metabolic explanations. Soc Sci Med. 2009; 69(2):223-8.

25. Ikeda A, Iso H, Toyoshima H, Fujino Y, Mizoue T, Yoshimura T, et al. Marital status and mortality among Japanese men and women: the Japan Collaborative Cohort Study. BMC Public Health. 2007 May 7;7:73. doi: 10.1186/1471-2458-7-73.

26. Woodward M, Brindle P, Tunstall-Pedoe H. Adding social deprivation and family history to cardiovascular risk assessment: the ASSIGN score from the Scottish Heart Health Extended Cohort (SHHEC). Heart. 2007;93(2):172-6.

27. Zhang Z. Marital history and the burden of cardiovascular disease in midlife. Gerontologist. 2006;46(2):266-70.
28. Malyutina S, Bobak M, Simonova G, Gafarov V, Nikitin Y, Marmot M. Education, marital status, and total and cardiovascular mortality in Novosibirsk, Russia: a prospective cohort study. Ann Epidemiol. 2004;14(4):244-9.

29. Cheung YB. Marital status and mortality in British women: a longitudinal study. Int J Epidemiol. 2000;29(1):93-9.

30. Yu Z, Nissinen A, Vartiainen E, Song G, Guo Z, Zheng G, et al. Associations between socioeconomic status and cardiovascular risk factors in an urban population in China. Bull World Health Organ. 2000;78(11):1296305.

31. Kamenský G, Dvoranová I, Murín J, Dlesk A. The national program for the prevention of diseases of the heart and blood vessels [Internet]. 2011 [cited 2016 Nov 2]. Available from: http://www.tvojesrdce.sk/files/ documents/31.pdf. (In Slovak.)

Received January 26, 2017 Accepted in revised form December 19, 2017 